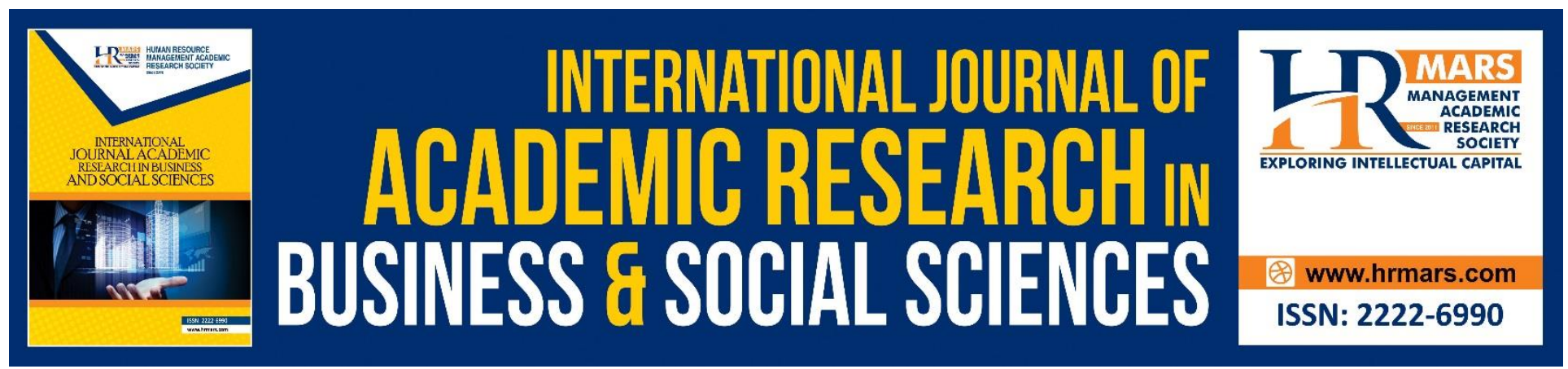

\title{
Inclusive Regional Development: A Case Study of Pengerang Region in Johor Malaysia
}

\author{
Maqsood Rezayee, Gabriel Hoh Teck Ling, Rahmatullah Ibrahimy and \\ Wahidullah Sadat
}

To Link this Article: http://dx.doi.org/10.6007/IJARBSS/v10-i6/7290

DOI:10.6007/IJARBSS/v10-i6/7290

Received: 26 April 2020, Revised: 28 May 2020, Accepted: 12 June 2020

Published Online: 20 June 2020

In-Text Citation: (Rezayee et al., 2020)

To Cite this Article: Rezayee, M., Ling, G. H. T., Ibrahimy, R., \& Sadat, W. (2020). Inclusive Regional Development: A Case Study of Pengerang Region in Johor Malaysia. International Journal of Academic Research in Business and Social Sciences, 10(6), 329-345.

Copyright: (c) 2020 The Author(s)

Published by Human Resource Management Academic Research Society (www.hrmars.com)

This article is published under the Creative Commons Attribution (CC BY 4.0) license. Anyone may reproduce, distribute, translate and create derivative works of this article (for both commercial and non-commercial purposes), subject to full attribution to the original publication and authors. The full terms of this license may be seen at: $\underline{\text { http://creativecommons.org/licences/by/4.0/legalcode }}$

Vol. 10, No. 6, 2020, Pg. $329-345$

http://hrmars.com/index.php/pages/detail/IJARBSS

JOURNAL HOMEPAGE

Full Terms \& Conditions of access and use can be found at http://hrmars.com/index.php/pages/detail/publication-ethics 


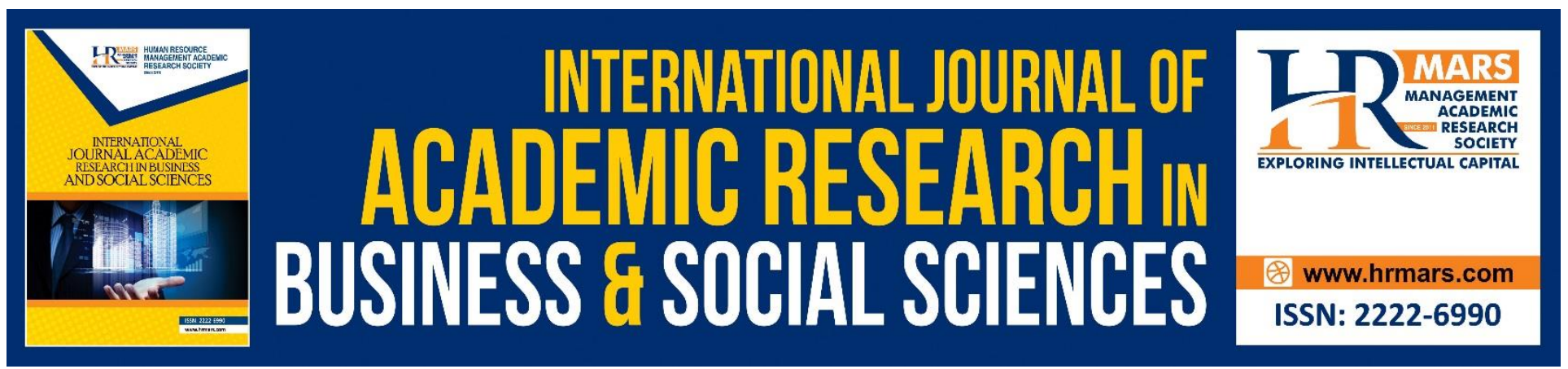

\title{
Inclusive Regional Development: A Case Study of Pengerang Region in Johor Malaysia
}

\author{
Maqsood Rezayee ${ }^{1}$, Gabriel Hoh Teck Ling², Rahmatullah Ibrahimy ${ }^{3}$ \\ and Wahidullah Sadat ${ }^{4}$ \\ ${ }^{1}$ Department of Architecture, Faculty of Engineering, Nangarhar University, Nangarhar, \\ Afghanistan, Department of Urban and Regional Planning, Faculty of Built Environment and
} Surveying, Universiti Teknologi, Malaysia, Skudai, 81310 Johor Bahru, Johor, Malaysia, ${ }^{2}$ Department of Urban and Regional Planning, Faculty of Built Environment and surveying, Universiti Teknologi,

Malaysia, Skudai, 81310 Johor Bahru, Johor, Malaysia, ${ }^{3}$ Department of Urban and Regional Planning, Faculty of Built Environment and surveying, Universiti Teknologi, Malaysia, Skudai, 81310 Johor Bahru, Johor, Malaysia, ${ }^{4}$ Department of General Technical Subjects, Faculty of Engineering, Nangarhar Univerity, Jalal Abad, Nangarhar, Afghanistan

Email:mqsoodrezay@yahoo.com, gabriel.ling@utm.my,ibrahimy.r@graduate.utm.my wahidullah.saidsherali@gmail.com

\begin{abstract}
The large development projects exhibit positive impacts on the surroundings and immediate spatial vicinity of the development. Pengerang Integrated Petroleum Complex (PIPC) is a mega project planned under Malaysia's National Key Economic Areas (NKEA). Even though the PIPC seems to be beneficial for the country's economic growth, in terms of foreign investment, however, it also creates controversial issues among local people, such as the local people may not necessarily obtain benefits from the development of PIPC. Previous similar studies did not adequately explore these issues. Therefore, this research study presents two main objectives: (i) to explore the issues and benefits of those arising among local people by the development of PIPC projects and (ii) to prepare a strategic plan for inclusive development where local people can benefit from the development of PIPC projects. In order to reach the aim of this research site observation, and interviews with community leaders, local workers, and government institutions, have been as an instrument for data collection. However, the finding of this research indicates that the issues of the PIPC development that were considered are those arising among the fishermen community in the region, local businesses, and other related issues. While this research study has been prepared, the strategy where local people can benefit from the development. Furthermore, an initiative and a well-designed strategy of this research study will lead to relatively long term support and a relationship between locals and the government.
\end{abstract}

Keywords: Inclusive, Regional Development, Pengerang, Benefit, Government Intervention 
INTERNATIONAL JOURNAL OF ACADEMIC RESEARCH IN BUSINESS AND SOCIAL SCIENCES

Vol. 10, No. 6, June, 2020, E-ISSN: 2222-6990 @ 2020 HRMARS

\section{Introduction}

The large development projects exhibit positive impacts on the surroundings and immediate spatial vicinity of the development (Batey et al., 1993; Shen et al., 2007; Sev, 2009). Economic, demographic, and social impacts exist that result from infrastructural investment (Xiahou et al., 2018). These impacts are usually of two types: those associated with the construction of the infrastructure and those associated with its operation (Warr et al., 2010; Ansar et al., 2016; Xiahou et al., 2018). Depending upon the actual infrastructural development, such impacts will demonstrate differing importance, relative both to each other and to socio-economic changes, resulting from other causes (Warr et al., 2010; Ansar et al., 2016; Xiahou et al., 2018).

Pengerang is located in the Southern Eastern tip of Peninsular Malaysia, in the State of Johor. The Johor State Government selected Pengerang as a catalyst project for the rural transformation program (Hishammuddina et al., 2018). As early as the 1970s, local people of Bandar Penawar were working in agriculture, particularly planting palm oil (Ngah, 1993). In the early 1980s, the development of Bandar Penawar started with the development of Desaru tourist resort (Ngah \& Saad, 2015). The resort consisted of hotels, chalets, as well as recreational and sporting facilities, including an international standard golf course. The resort planned to attract visitors from Johor Bahru and Singapore (Ngah \& Saad, 2015; Ngah, 2015; Zahid \& Nasir, 2016). Following that, the KEJORA (Johor Tenggara Development Authority) headquarters and an additional 100 units of KEJORA staff housing were developed in 1989 (Ngah \& Saad, 2015). Many KEJORA staff, who previously worked at a temporary KEJORA office in Johor Bahru, moved to the town in 1991 when the office was shifted to Bandar Penawar (Ngah \& Saad, 2015). Moreover, During the period 19901999, four secondary schools were established, including one secondary school, two secondary boarding schools, and a sport school (Ngah \& Saad, 2015; Che Man \& Salihin, 2018). Furthermore, during 2000-2010, four higher education institutions were established with total enrolment of more than 3,000 students. The development of the educational institutions in the region strengthened the economic base of the town and accelerated the growth of its population (Ngah \& Saad, 2015). The growth of population led to the growth of businesses, including the retail, restaurant, computer, food stall, stationary, telecommunication, and workshops (Ngah \& Saad, 2015; Zahid \& Nasir, 2016).

Post-2010, two main development projects exist. The first is the construction of the SenaiDesaru highway in 2012 (Ngah \& Saad, 2015; Rahman, 2018; Rohani et al., 2019). This highway links Senai Airport to Desaru, with a new bridge crossing the Johor River near Pasir Gudang. As a result, the Bandar Penawar and the Pengerang region became more accessible from the Johor Bahru Metropolitan area, and a journey from Pasir Gudang to Bandar Penawar only takes less than halfhour (Ngah \& Saad, 2015). The second is the development of the Pengerang Integrated Petroleum Complex (PIPC), which houses oil refineries, naphtha crackers, petrochemical plants as well as a liquefied natural gas (LNG) (Zahid \& Nasir, 2016). PIPC is located in Tanjung Pengerang, which is only 20 minutes to Bandar Penawar (Ngah \& Saad, 2015; Ngah, 2015; Zahid \& Nasir, 2016; Rahman, 2018; Rohani et al., 2019). The selection of the site is attributed to a number of natural and fortunate circumstances. The Pengerang coastline ensures a safe and sheltered harbor where no breakwater is required for coastal development (Rahman, 2018). With the strategic location of shipping lanes from the Middle East- Singapore- China and being adjacent to Singapore, it will be a big step in creating value for the downstream oil and gas value via petrochemical refining industry in Johor and Malaysia (Ngah \& Saad, 2015; Ngah, 2015; Zahid \& Nasir, 2016; Rahman, 2018; Rohani et al., 2019). Then, the PIPC began in 2011 as the Refinery and Petrochemical Integrated Development (RAPID) project, in 
response to the realization that gas resources in Peninsular Malaysia were finite, limiting the growth of the gas-based petrochemical industry (Ngah \& Saad, 2015; Zahid \& Nasir, 2016; Rahman, 2018; Che Man \& Salihin, 2018). PIPC is a mega project planned under the Malaysia's National Key Economic Areas (NKEA), including several parts: The Pengerang Integrated Complex (PIC), Refinery and Petrochemical Integrated Development (RAPID) project, other ancillary facilities, Independent Deepwater Petroleum Terminal (PIDPT), and Pengerang Maritime Industrial Park (PMIP) (Ngah \& Saad, 2015; Zahid \& Nasir, 2016; Che Man \& Salihin, 2018; Rahman, 2018; Rohani et al., 2019). Besides, within the PIPC, land parcels allocated for the downstream industries and related infrastructures also exist. Outside the PIPC areas, a few townships are also being proposed to accommodate the workers and populations generated from the projects, including a township for the resettlement of the villages affected by the PIPC project (Ngah \& Saad, 2015; Zahid \& Nasir, 2016; Che Man \& Salihin, 2018; Rahman, 2018). The expectation exists that PIPC creates 50,000 new jobs opportunities throughout its development process, and it will generate 4,000 new jobs upon completion (Ngah \& Saad, 2015; Ngah, 2015; Zahid \& Nasir, 2016). In addition, the whole development of PIPC will see a total estimated investment of approximately RM 120 billion and is expected to boost Malaysia's Gross National Income (GNI) by an additional RM 20 billion by 2020 (Zahid \& Nasir, 2016; Rahman, 2018). Figure 1 shows the map of Pengerang.

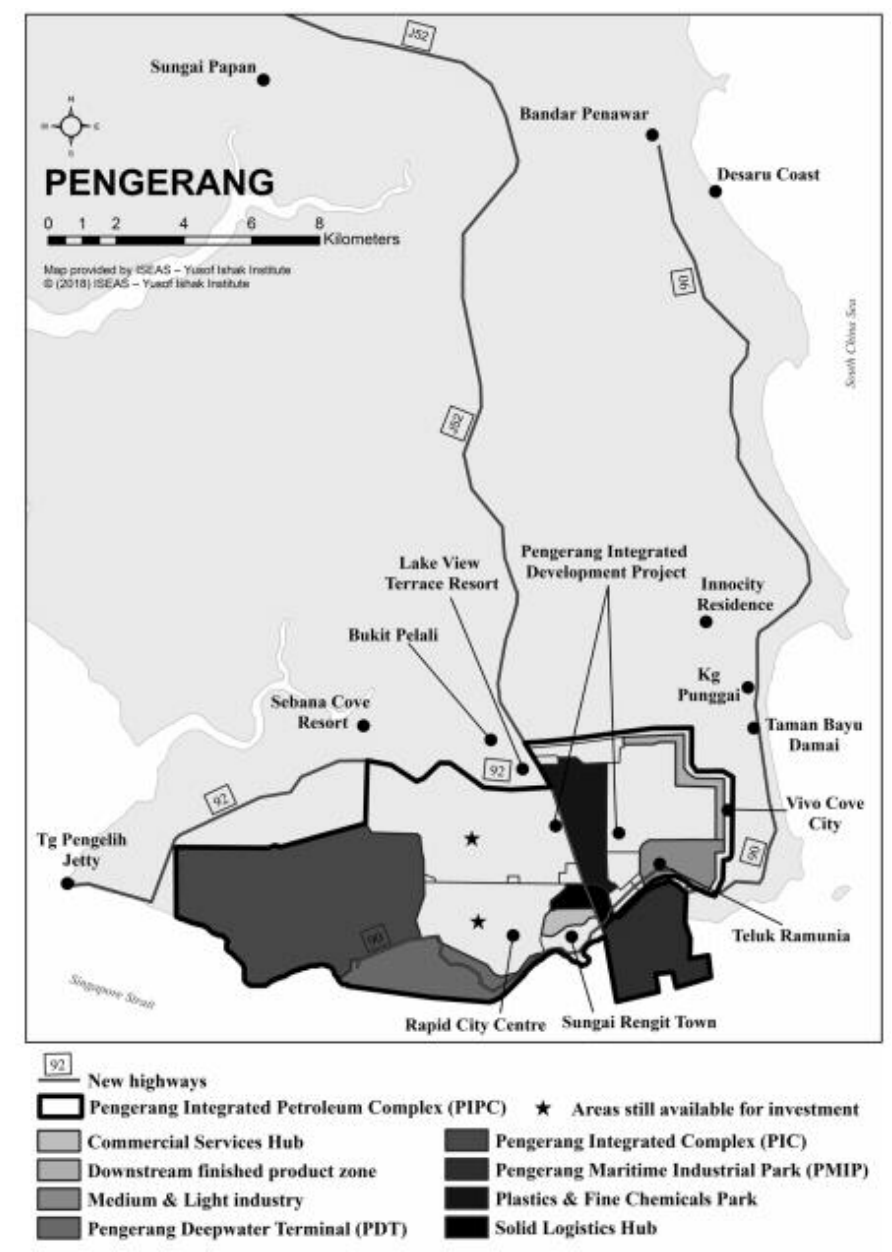

Figure 1. Map of Pengerang (Rahman, 2018). 
INTERNATIONAL JOURNAL OF ACADEMIC RESEARCH IN BUSINESS AND SOCIAL SCIENCES

Vol. 10, No. 6, June, 2020, E-ISSN: 2222-6990 @ 2020 HRMARS

However, even though the Pengerang Integrated Petroleum Complex (PIPC) seems to be beneficial for the country's economic growth, in terms of foreign investment, however, it also provides controversial issues among local people. For example, the local people are less beneficial in the development of PIPC as they did not utilize or rely on local resources in terms of employment, in addition to the fact that the product and services offered did not benefit the local community (Ngah \& Saad, 2015; Ngah, 2015; Zahid \& Nasir, 2016). Moreover, the business people voiced their concern on the high price of business premises in Bandar Penawar and around the region, which are beyond their affordability. They commented that the new development in Pengerang Region could marginalize the local Malay communities that cannot afford to own properties and compete in business (Ngah \& Saad, 2015; Ngah, 2015; Zahid \& Nasir, 2016). However, previous similar studies did not adequately explore these issues which based on them to be prepared strategy and initiative where local people could benefit from the development.

Therefore, this research exhibits two main objectives: (i) to explore the issues and benefits of those arising among local people by the development of PIPC projects, with consideration of the current economic activities of the Pengerang community in terms of nature of economic development, the demand for human capital, and supporting services, and (ii) to prepare strategic plan for inclusive development in the Pengarang region that will provide opportunities for local people to participate in economic development, enhancing their capacity to benefit from the development, which in turn will raise their income and wellbeing in sustainable way.

\section{Literature Review}

The term development, mostly recognized by a framework in which economic growth, was believed to be the most important driver of socio-economic development (Gent, 2017). However, it became clear that economic growth did not sufficiently ensure the improvement of welfare and wellbeing (Gent, 2017; Lee, 2019). Different factors such as social, economic, political, cultural, and environmental factors in a country-specific context determine development needs and challenges (Dawkins, 2003). When building a conceptual understanding of inclusive development, two issues thus arise: first, the distinction between growth and development; and second, the import of the term inclusive (Raunayar \& Kanbur, 2009; Gent, 2017). "Development brings into play dimensions of wellbeing beyond simply income, while inclusive focuses attention on the distribution of wellbeing in society" (Raunayar \& Kanbur, 2009). Furthermore, growth demonstrates a very clear connection with per capita income. Therefore, an increase in per capita income means positive growth. However, development involves other dimensions of well-being, like education and health (Raunayar \& Kanbur, 2009; Royon \& Geiser, 2009).

Inclusive focus on the distribution of something among the society, for example, pro-poor growth, which means reducing income poverty (Gupta, et al., 2015; Widianingsih \& Paskarina, 2019). Conversely, inclusive growth means that it must be accompanied by lower-income inequality (Pouw \& Gupta, 2017). Thus, growth can be pro-poor without being inclusive, meaning that the poverty percentage is falling, however, income inequality is still high (Raunayar \& Kanbur, 2009). A good example to explain more about the difference between growth and development is the Human Development Index (HDI) (Raunayar \& Kanbur, 2009). In this well-known index, the per capita income of a country is combined with two other indicators: education, which is measured by the literacy rate, and health, measured by the life expectancy. This example shows how development involves other measures of well-being (Raunayar \& Kanbur, 2009). 
Inclusive development is therefore defined as a development model that promotes equality and the widest social participation in the planning, implementation, and monitoring of the development process (Royon \& Geiser, 2009; Guchait, 2017). Four levels of participation of citizens exist. First is information sharing, and this is a limited form of participation where citizens are informed about the decisions of the local government. Second, consultation, where citizens are consulted prior to decisions being taken or programs being implemented, but no assurance that their opinions will be taken into consideration is found in this model. Third is participation, and this step gives citizens the right to negotiate the planning and strategies, as well as monitor the implementation and follow-up. Fourth is co-decision, and this is the ultimate form of participation of citizens in decision making and implies power-sharing from the local government towards the community (Raunayar \& Kanbur, 2009; Royon \& Geiser, 2009; Gupta \& Vegelin, 2016, Guchait, 2017).

Furthermore, inclusive development gives the same opportunity for people with disabilities to enjoy the rights as other members of the community, as well as to be as human capital sources of knowledge and expertise regarding the design and implementation of development policies (Royon \& Geiser, 2009; Diebolt, \& Hippe, 2019). Excluding any group of people from development based on their gender, ethnicity, age, disability or poverty leads to rising levels of inequality around the world (Royon \& Geiser, 2009; Tsymbaliuk, 2019). Development cannot effectively reduce poverty unless all groups contribute to the creation of opportunities, share the benefits of development, and participate in decision-making (Gupta et al., 2015). Then, development is considered inclusive when the benefits of development reach all those that make up the poor in the region. These include women and children, minority groups, the extremely poor, and even disabled (Ngah, 2015)

Thus, a move from just growth to inclusive development involves two steps: first to be evaluate the distribution, average level of welfare, and well-being along any dimension considered and second to include dimensions other than income in assessing performance (Raunayar \& Kanbur, 2009). To move from growth to inclusive growth, the first step can be taken into consideration, with focusing on the income dimension. To move from growth to development, the second step can be taken into consideration with inclusion of non-income dimensions, with focusing on average achievement. While in inclusive development as a concept, both steps need to be considered (Raunayar \& Kanbur, 2009).

\section{Study Area}

Pengerang is located in the Southern Eastern tip of Peninsular Malaysia, in the State of Johor (Hishammuddina et al., 2018). The Johor State Government selected Pengerang as a catalyst project for rural transformation program (Ngah, 1993; Ngah \& Saad, 2015; Zahid \& Nasir, 2016). The area saw an increase of investments and development over the past few years, which are sourced from the Pengerang Integrated Petroleum Complex (PIPC) (Rohani et al., 2019). Its boundary touches Tanjung Surat from the North and Pantai Timorn from the Western side, whereas it is surrounded by sea from its Southern side (Che Man \& Salihin, 2018). Figure 2 shows a map of the study area. 


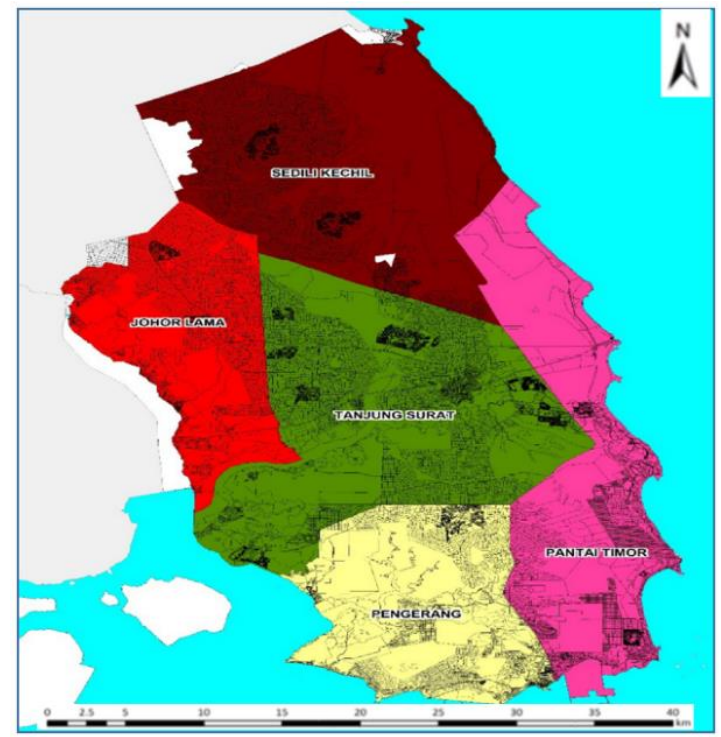

Figure 2. Map of study area (Pihak Berkuasa Tempatan Pengerang, 2019).

\section{Methodology}

To collect and analyze the data for this research, certain steps were followed. The data have been collected based on primary data and secondary data. Prior to primary data collection, the preliminary understanding could aid the researcher to gain a comprehensive understanding and test the feasibility of a more extensive study. Secondary data have been obtained through reviewing different books, dissertations, Master Thesis, Ph.D. Thesis, Journals, Research Reports, Government Constitutions, Seminar Papers, and Government Guidelines. This secondary data have been reviewed to obtain a better understanding of the current economic situation in term of nature of economic development, the demand for human capital, and supporting services. Secondary data will also have facilitated knowledge regarding how others designed the initiative and strategic plan for inclusive development in regional areas, which provided opportunities for local people to participate in economic development.

Site observation, as the first stage of primary data collection, was conducted on the aspects of environmental capital, infrastructure capital, and other supporting services, to gain deep knowledge regarding the community's benefit in terms of infrastructure such as highway, road expansion, and its related benefits. Following the site observation, an interview was used as an instrument in data collection. Therefore, keeping in mind the scope of work, two types printed preset open-ended questions were prepared, one for community leader and local workers while the other has been intended for government institutions. Each question was tagged a number to ease the sorting of each group of the interviewees. The interview was conducted to demonstrate better knowledge of the current economic activities of the Pengerang community in terms of nature of economic development, the demand for human capital, and supporting services, in addition to present a clear view on the issues and benefits that are arising among local people by the development of PIPC projects. Additionally, a goal is to understand the gap between the demands for human capital and supporting services derived from new economic development and the capacity of local people to fulfill the demand. The interviewees have been selected spontaneously and randomly based on their knowledge and experience. Community leaders, director, and members of 
INTERNATIONAL JOURNAL OF ACADEMIC RESEARCH IN BUSINESS AND SOCIAL SCIENCES Vol. 10, No. 6, June, 2020, E-ISSN: 2222-6990 @ 2020 HRMARS

fishery department have been selected for interview spontaneously. however, interviewees from the skilled, semi-skilled, non-skilled workers, shop owners, restraint owners and businessmen have been selected randomly for this research study. Table 1 shows the profile of interviewees.

Following the data collection, the gathered data were taken under the process of examining, summarizing, and drawing a conclusion. The data analysis includes qualitative data analysis, and a content analysis was used. The content analysis includes different steps such as getting familiar with the data, coding and labeling the transcript, creation of categories (themes) by bringing several codes together, defining and naming the themes, and writing up the result (Burnard et al., 2008). In this research, first, the interview transcript was read carefully regarding the related sentences, phrases, and sections that were labeled and coded, and the coded and labeled data were assigned three categories: first, economic activities of Pengerang Community; Second, issues of the development; And third, existing impacts/benefits received from the development. Each category was named for result writing up.

The result and finding which arise from content analysis, were written clearly in different themes. Conclusions and recommendations are the last step of this research. In this step, conclusions were drawn based on the data analysis and results. These conclusions helped in recommending how the issues can be alleviated and how improvement can be done in the study area.

Table 1. Interviewees Profile

\begin{tabular}{llll}
\hline Number & Position & Agency & $\begin{array}{l}\text { Number of } \\
\text { Interviewees }\end{array}$ \\
\hline 1 & Director & Fishery Department & 1 \\
\hline 2 & Member & Fishery Department & 3 \\
\hline 3 & Community Leaders & Pengerang Region & 3 \\
\hline 4 & Skilled-semi skilled, & $\begin{array}{l}\text { Workers from } \\
\text { different countries }\end{array}$ & 10 \\
& non-skilled workers & in PIPC & \\
\hline 5 & Restaurant owners & - & 6 \\
\hline 6 & Street shop owners & - & 4 \\
\hline 7 & Businessmen & - & 5 \\
\hline Total & & & 32 \\
\hline
\end{tabular}

\section{Result and Finding}

This section of research presents the finding and results which were obtained through primary and secondary data. The results and findings present economic activities of the Pengerang community, issues, and benefits of the development. According to this finding, the strategy was designed so that local people could benefit from the development.

\section{Economic Activities of Pengerang Community}

The main livelihood activities of the previous generation in Pengerang were focused on fishery and agriculture. Agriculture has been source of employment in the Pengerang region for a long time. Palm oil is the major product from the agricultural sector produced by local people (Ngah, 1993). In 1980, about six out of ten workers depended on primary resources such as agriculture, hunting forestry, and fishing for their livelihoods (Ngah, 1993). However, the numbers changed 
INTERNATIONAL JOURNAL OF ACADEMIC RESEARCH IN BUSINESS AND SOCIAL SCIENCES Vol. 10, No. 6, June, 2020, E-ISSN: 2222-6990 @ 2020 HRMARS

between 1980 and 1990. Employment in the agricultural sector declined significantly over the past two decades. This is because of development of Bandar Penawar, development of Desaru tourist resort, development of KEJORA headquarters, and establishment of academic institutions (secondary school, secondary boarding schools, and higher education institutions), which lead to population growth. Therefore, the growth of population led to the growth of businesses, including the retail, restaurant, computer, food stall, stationary, telecommunication, and workshops (Ngah \& Saad, 2015; Ngah, 2015; Zahid \& Nasir, 2016).

Based on director of fishery department "The fishery is still active in the region since it exhibits a demand for fish in terms of new restaurant running. For fishery, two types of fishing activities exist, first in the open sea and second fishing in the river. Any kind of development will exhibit more impact on the fishery. The government has been very supportive of fishery as it provided initiatives including allocation for their living expenses, which 300 RM per month. The government also provided fuel subsidies to the fishermen, which is a $70 \%$ discount on the price of oil to ease their burden."

Tourism, which is another livelihood activity in the region, the developments are not so much in the Pengerang region. Most of the tourism developments are focused on Bandar Penawar (Ngah \& Saad, 2015). However, under the Desaru Coast Project, a plan was in place for ecotourism development, which includes tourism destination, luxury hotel (5-6 stars) theme park, and a business and real estate center. The expectation exists that the development of theme parks will be one of the main attractions for tourism in the region (Ngah \& Saad, 2015). See below in Figure 3 regarding the tourism development in Pengerang.

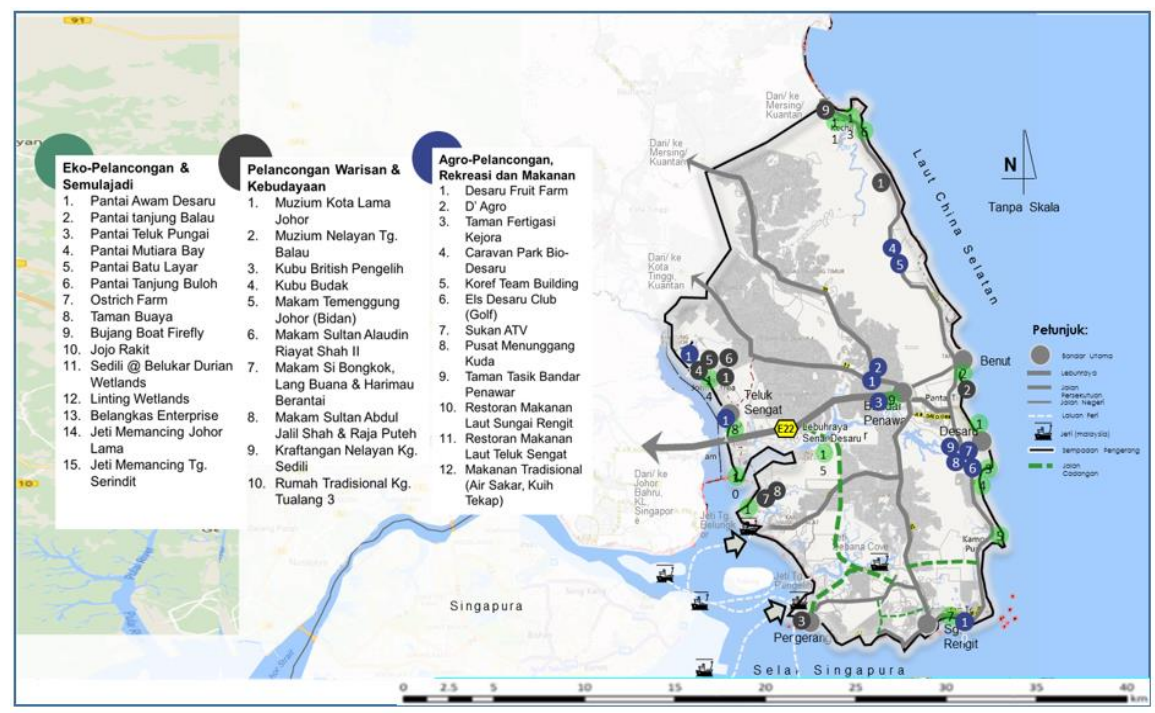

Figure 3. Tourism developments in Pengerang (Pihak Berkuasa Tempatan Pengerang, 2019).

In terms of industry now, the region has become the most intensive oil and gas activity in Malaysia. Specially, PIPC, which began in 2011 as the Refinery and Petrochemical Integrated Development (RAPID), provided huge potential for industrial development in the region (Ngah \& Saad, 2015). PIPC includes the following several parts: The Pengerang Integrated Complex (PIC), Refinery and Petrochemical Integrated Development (RAPID) project, other ancillary facilities, Independent Deepwater Petroleum Terminal (PIDPT), and Pengerang Maritime Industrial Park (PMIP) (Ngah \& Saad, 2015; Zahid \& Nasir, 2016; Che Man \& Salihin, 2018; Rahman, 2018; Rohani et al., 
INTERNATIONAL JOURNAL OF ACADEMIC RESEARCH IN BUSINESS AND SOCIAL SCIENCES Vol. 10, No. 6, June, 2020, E-ISSN: 2222-6990 @ 2020 HRMARS

2019). Besides, within the PIPC, land parcels are also present allocated for the downstream industries and related infrastructures. Outside the PIPC areas, a few townships are also being proposed to accommodate the workers and populations generated from the projects, including a township for the resettlement of the villages affected by the PIPC project (Ngah \& Saad, 2015; Ngah, 2015; Zahid \& Nasir, 2016; Rahman, 2018).

The expectation exists that PIPC creates 50,000 new jobs opportunities throughout its development process, and it generates 4,000 new jobs upon completion (Ngah \& Saad, 2015; Ngah, 2015; Zahid \& Nasir, 2016). In addition, the whole development of PIPC will see a total estimated investment of approximately RM 120 billion and is expected to boost Malaysia's Gross National Income (GNI) by an additional RM 20 billion by 2020 (Zahid \& Nasir, 2016; Rahman, 2018). According to an interview with Asif Watto Pakistani semi-skilled worker, "most of non-skilled workers were paid according to hours, which is RM 8-RM 12 per hour. Skilled workers received salary of RM 12-RM 18 per hour. Sometimes for expert workers, their salary could go up to RM 22". However, Azhar Majeed Pakistani Supervisor indicates that "in terms of job hiring, the majority of the workers are foreign labor. Foreign workers come from many countries such as China, Bangladesh, Pakistan, Japan, Spain, Thailand, Vietnam, and others. However, only 20\% of them are local people, who work in the management sector". In addition, based on Pihak Berkuasa Tempatan Pengerang, (2019) the Pengerang region demonstrates huge potential for industrial development. The local authority of the Pengerang proposed industries in different locations. Figure 4 shows the Potential Industry in the Pengerang region.

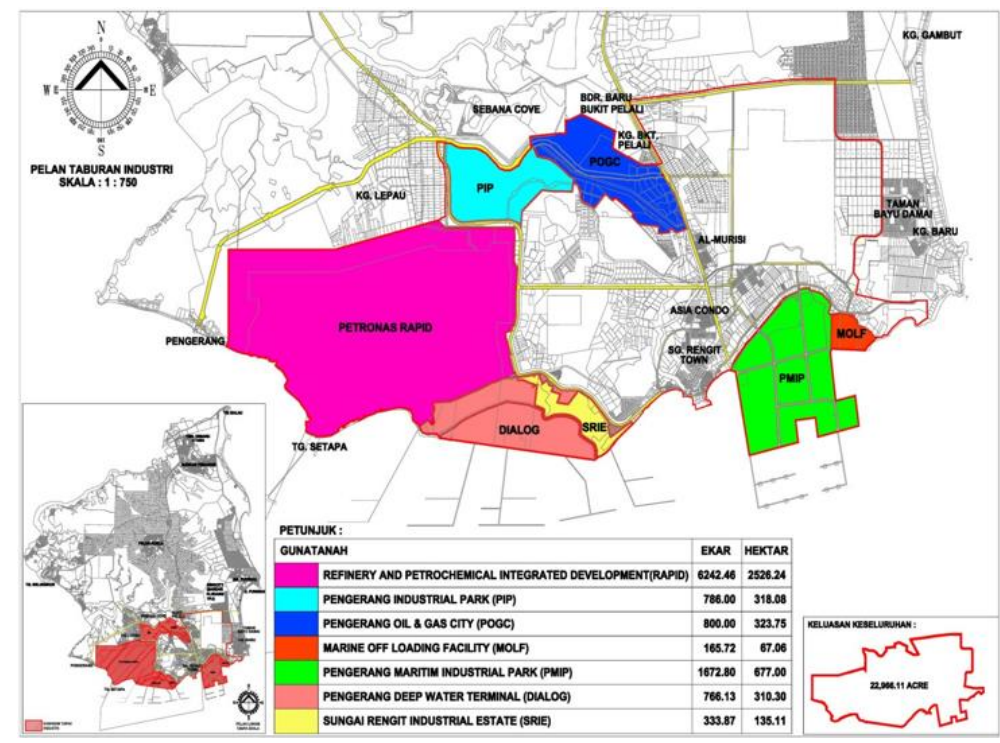

Figure 4. Potential industry in Pengerang region (Pihak Berkuasa Tempatan Pengerang, 2019).

\section{Issues of the Development}

The development of the region also caused a few controversies among the local authority. The issues that were considered are those arising among the fishermen community in the region, local business, and other related issues that were posed by the development of the PIPC projects.

It is quite an issue for the fishermen as they are the most affected group by the development of Pengerang Integrated Petroleum Complex (PIPC). The development of PIPC has taken up many 
land areas and that would include the fishing areas as well. When their areas were used for oil and gas development, those changes will result in a decrease of fish catchment. Moreover, director of fishery department state that "in terms of skills, the fishermen do not possess the skills to work in land and cannot adapt to development. Furthermore, fishermen onshore are not ready to participate in working in the mega projects as they used to work in the open sea. However, working on the sea is seasonal, and the fishermen usually do not possess the capital for each season."

In terms of businesses, the businessmen are the second group of people who are affected by the development of the Pengerang Integrated Petroleum Complex (PIPC). The issue that arises includes the fact that the land price increased. When the land price increases, other factors are affected such as shop rent; therefore, the rent becomes more expensive than before. The rent could be up to RM 5,000- RM 12,000 for the double story shop. For those who possess their land, it will be an advantage compared to those who did not own the land. Moreover, most of the workers are temporary, and they will move out when they finish the construction. This leads to an issue of how the businesses will survive for the long term. Furthermore, the improvement of region increases the competitiveness among the community members (Hwang et al., 2018). Therefore, another issue for local businesses is competition with foreign business. The local businesses need to compete with outsiders regarding running restaurants, due to presence of foreign workers in development of PIPC. As the Shahid syfi bin Samsuddin, restaurant owner indicates that "the PIPC projects did affect me. A few years ago, I was running a workshop but the government grabbed the land, hence I have moved out. The development of the areas also affected my economic activity as the price increase like the rent of the shop and it is hard for me to get the benefits from the development. It would be better if the government put us as their priority in tandem of the development. It will be great if government gives us shop lots without have to pay the rent."

Development of mega projects causes the degradation of the environment and natural resources, as well as require the relocation of population, affecting economic activities and also creating stress to human, animals, and plants around the zoon (Chavez et al., 2013). Hence, the community leader states that "safety of the local people is the issue among the Pengerang community. Since PIPC development altered the physical environment by expanding the road, the local people must deal with heavy trucks that come and go in the areas, and this concerns them in terms of road and traffic safety."

\section{Existing Impacts /Benefits Received from the Development}

Regarding direct benefits, the locals raise their income through night markets that open near the foreigner camp. The night market opens three times per week. This will help the local community to improve their socioeconomic conditions. Sialzax, a Chinese shop owner states that "I would say that the RAPID project helps us a lot. I have been running the business for 18 years and previously, there were not so many people in the region, and so our business was not doing well. Now, since there is RAPID project, the number of customers increases. Most of our customers are foreigner who works at the PIPC".

Furthermore, the development of large projects benefits the community in terms of infrastructural development. Then, due to the development of the RAPID project, the community also benefits in terms of infrastructure such as highway, road expansion, and its related benefits.

Factors behind the different economic performance in regions and communities relate to an interplay of local and global forces (Ida \& Terluin, 2003). In this context, development in regions 
INTERNATIONAL JOURNAL OF ACADEMIC RESEARCH IN BUSINESS AND SOCIAL SCIENCES Vol. 10, No. 6, June, 2020, E-ISSN: 2222-6990 @ 2020 HRMARS

depends on complex economic, social, and political processes, in which the various groups of actors attempt to achieve outcomes commensurate from direct and indirect job affordability (Ida \& Terluin, 2003). Therefore, development of PIPC offers indirect job opportunities in term of supporting services. These jobs are mostly filled by locals to achieve outcomes commensurate, and they include food and beverage services, maintenance and cleaning services, as well as shops for clothing and other housing apparatus.

\section{Discussion and Strategies for Local Community Development}

After discussing with community leaders, government constitutions, and local workers, reviewing current economic growth and development of the Pengerang region, as well as exploring the issues and benefits those arising among local people by the development of PIPC projects, it is quite evident that the locals need government intervention to receive the full benefits of the PIPC projects. Below is the strategy and initiative of this research for inclusive development in the Pengarang region that will provide opportunities for local people to participate in economic development, in addition to enhancing their capacity to benefit from the development which in turn will raise their income and wellbeing in sustainable way.

The fisherman community needs government intervention to be able to become a part of this development and not be negatively affected by the development. Besides, they need special attention as they are more economically fragile due to PIPC projects because these projects will exhibit an impact on the eco-system. As their current fishing areas are being affected by the development, they need to invest in more advanced fishing techniques into the sea. Conversely, they do not possess enough capital to purchase new advanced equipment like a bigger boat to go deepsea fishing. Therefore, financial support from the government is necessary to upgrade the fishing industry in the area. In addition, the government should initiate constant monitoring of the resource situation to ensure that no overexploitation occurs. Besides, fishermen lack knowledge of modern fishing techniques, so they need training. The fishery department should provide the proper training for the fishermen; therefore, they can demonstrate better catchment through the usage of all those fishing techniques. Moreover, they also need a proper jetty space to support the new advance fishing methods. The government can help them with issues like this by building a bigger and better jetties for fishermen. Another thing that can be introduced to fishermen is fish farming using seawater near the shore to ensure steady fish production. Alternatively, this can also become a tourism spot by providing fishing facilities to the public, creating more earning opportunities for the fishermen. This is a good strategy where fishermen do not just depend on open sea fishing but also can rely other activities. Additionally, since the development of fresh seafood restaurants, knowledge about multinational cuisine can attract more visitors in the region (Hasan \& Siddique, 2016). Therefore, introducing them alternative livelihoods so they can take different opportunities such as fresh seafood restaurants. Also, by learning about multi-national cuisine, more foreign visitors and foreign workers at PIPC become interested to visit the site, and this can increase their income

The micro-credit finance program benefits the locals in terms of running small businesses (Mackinnon et al., 2002; Taiwo et al., 2012). For the support of the local businesses, the government needs to introduce a micro-credit finance programs for the locals to start small businesses. The local people can avail to micro-credit finance to invest in the area. This will benefit the locals in terms of receiving advantage from the development. Furthermore, since the prices have been high with the construction of the PIPC, the local people are not matching the investment needed for opening even 
small businesses. Thus, government must allocate a specific site for local's shops/markets to provide affordable space for them. Then locals possess an affordable space and can focus their capital on buying more goods than paying rent for the places. Furthermore, possessing affordable space means they demonstrate higher chances of receiving a good return from the investment in the area. Besides, for the private sector who employ local people in their business, a tax exemption can be introduced to encourage them to employ more local people.

The innovation and ecological modernization benefits the businessmen by providing more business opportunities (Gibbs, 2003). Currently, the locals are relying on traditional businesses in the Pengerang region. Also, local people should explore more business opportunities other than just food and clothing, such as shops like money grams and western unions, so that workers can send money back to their home country. By exploring avenues like a money gram or western union, they will expand the businesses.

Furthermore, in recent years, a great deal of interest exists in the relationships between technological innovation and regional development (Masser, 2016). A good demand for information and communication technology (ICT) shops and technical services in Pengerang also is present, which small businesses can provide. They would also need skill training for ICT operations and services. Therefore, training schemes should be introduced for information and communication technology, focusing on the local people. The introduction of such training on ICT will help the local community open up shops for ICT services. Furthermore, understanding the role of the cultural economy in regional development is also interesting (Florida et al., 2008; Diebolt \& Hippe, 2019). Then, language training courses should exist for English and other foreign languages, to make communicating with each other easier for the local people and foreign workers. Knowing the international cultures and languages will reduce the language gap. As a result, good communication with internationals will bring a positive impact on their businesses and will raise their income.

Moreover, based on the interview with community leaders, currently, many international people are performing business illegally in the region. Therefore, law enforcement should be stricter to ensure no illegal businesses grow in that area and to ensure fair growing opportunities for the local businesses. Law enforcement can be performed by regular visits of the customs authority, immigration, and police, to make sure that no one is performing illegal business in the regions. Furthermore, this will also help in increasing revenue by tax collection, which can be invested in the locals to compete with international workers and businessmen.

For other issues regarding road safety, especially pedestrian movement, improvement of the road system, infrastructure signage, and pedestrian facilities (walkways, zebra crossing, and street furniture) in the town center, should be addressed. This will not only decrease the road accident ratio but also increase the accessibility for visitors and tourists. Moreover, town centers need to be attractive; thus, beatifications should also be performed there in terms of planting trees and flowers.

\section{Conclusion}

The large development projects exhibit positive impacts on the surroundings and immediate spatial vicinity of the development (Batey et al., 1993; Shen et al., 2007; Sev, 2009). Economic, demographic, and social impacts exist that result from infrastructural investment (Xiahou et al.,2018). PIPC as a catalyst project for the rural transformation program in the Southern Eastern tip of Peninsular Malaysia seems to be beneficial for the country's economic growth, in terms of foreign 
investment; however, it also creates controversial issues among local people, such as the fact that local people may not necessarily obtain benefits from the development of PIPC (Ngah \& Saad, 2015).

However, based on the findings of this research, the issues that were considered are those arising among the fishermen community in the region, local business, and other related issues. In terms of the fishermen community, development of PIPC has taken up many land areas and that would include their fishing areas. When their areas were used for oil and gas development, those changes will result in a decrease in fish catchment. in terms of skills, the fishermen do not possess the skills to work in land and cannot adapt to development. Furthermore, fishermen onshore are not ready to participate in working in the mega projects as they used to work in the open sea. The businessmen are the second group of people who are affected by the increase of land price, and its affected factors include the increase shop rent, which has been posed by the development of the (PIPC). Moreover, most of the workers are temporary, and they will move out when they finish the construction. This leads to an issue of how the businesses will survive for the long term. Besides, another issue for local businesses is competition with foreign business. The local businesses need to compete with outsiders regarding running restaurants, due to presence of foreign workers in development of PIPC. Apart from that, another issue that arises is the language and cultural gap between local and international workers. Adapting to foreign people is difficult for local people since differences exist in languages and cultures.

However, the finding of this research indicates that, the locals need government intervention to receive the full benefits of the PIPC projects. The fishermen, they need special attention as they are more economically fragile due to PIPC projects because these projects will exhibit an impact on the eco-system. As their current fishing areas are being affected by the development, they need to invest in more advanced fishing techniques into the sea. Conversely, they do not possess enough capital to purchase new advanced equipment like a bigger boat to go deep-sea fishing. Therefore, financial support from the government is necessary to upgrade the fishing industry in the area. Furthermore, the fishery department should provide the proper training for the fishermen; therefore, the fishermen can demonstrate better catchment through the usage of all those fishing techniques. However, for the support of the local businesses, the government needs to introduce a micro-credit finance programs for the locals to start small businesses. The local people can avail to micro-credit finance to invest in the area. This will benefit the locals in terms of receiving advantage from the development. In addition, government must allocate a specific site for local's shops/markets to provide affordable space for them. Then locals possess an affordable space and can focus their capital on buying more goods than paying rent for the places. Furthermore, possessing affordable space means they demonstrate higher chances of receiving a good return from the investment in the area. For other issues regarding road safety, especially pedestrian movement, improvement of the road system, infrastructure signage, and pedestrian facilities (walkways, zebra crossing, and street furniture) in the town center, should be addressed. This will not only decrease the road accident ratio but also increase the accessibility for visitors and tourists. Moreover, town centers need to be attractive; thus, beatifications should also be performed there in terms of planting trees and flowers.

With all above, however, this research has prepared the strategy and initiative program, where local people can benefit from the development, and then, will contribute to provide opportunities for local people to participate in economic development, enhancing their capacity, which in turn will raise income and wellbeing in sustainable way. Moreover, the prepared strategy and initiative of this research would contribute to change the relationship between the government 
and local residents (skilled workers, non-skilled workers, businessmen and fishermen). This relationship supports the locals in term of human capital, economic capital, and infrastructure capital, to compete with international workers in order to raise their income and benefit from the development. Furthermore, the initiative and well-designed strategy will contribute to lead to relatively long-term support and a relationship between local and government. With the implementation of this prepared strategy, wellbeing of locals will be raised in sustainable way; therefore, their lifestyle will improve, and they can use their capital more efficiently.

However, this research is not without limitations. First, the data were gathered through an interview with the community leader and the government institutions. Therefore, because of unwillingness, they might respond to the questions without thinking, quickly, and incorrectly. Secondly, the researchers did not receive permission to enter inside the PIPC campus to interview the director or official of PIPC in order to hear their point of view regarding the project's impact on the local communities. Finally, further research is needed to research the implementation and adaptation stage of the PIPC and its impact on the local community, in term of businesses, per-capita income, fishery, tourism, job skills, and adaptation with the intentional workers.

Author Contributions: All authors contributed equally to this work.

Conflicts of Interest: The authors declare no conflict of interest.

\section{References}

Ansar, A., Flyvbjerg, B., Budzier, A., \& Lunn, D. (2016). Does infrastructure investment lead to economic growth or economic fragility? Evidence from China. Oxford Review of Economic Policy, 32 (3), 360-390.

Batey, P. W., Madden, M., \& Scholefield, G. (1993). Socio-economic Impact Assessment of Largescale Projects using Input-Output Analysis: A Case Study of an Airport. Regional Studies, 27(3), $179-191$.

Burnard, P., Gill, P., Stewart, K., Treasure, E., \& Chadwick, B. (2008). Analyzing and presenting qualitative data. British Dental Journal, 204 (8), 429-432. doi: 10.1038/sj.bdj.2008.292.

Chavez, H., Nadolnyakb, D., \& Saraviac, M. (2013). Socioeconomic and Environmental Impact of Development Interventions: Rice Production at the Gallito Ciego Reservoir in Peru. International Food and Agribusiness Management Review,16, (1).

Che Man, N., \& Salihin, A. F. (2018). Analyzing Land Use Pattern changes in Mukim Pengerang, Johor, Malaysia. Geoplanning: Journal of Geomatics and Planning, 5(2), 229-236. 10.14710/geoplanning.5.2.229-236.

Dawkins, C. J. (2003). Regional Development Theory: Conceptual Foundations, Classic Works, and Recent Developments. Journal of Planning Literature, 18 (2), 131-171. doi:10.1177/0885412203254706.

Diebolt, C., \& Hippe, R. (2019). The long-run impact of human capital on innovation and economic development in the regions of Europe. Applied Economics, 51(5), 542-563. DOI:10.1080/00036846.2018.1495820.

Florida, R., Mellander, C., \& Stolarick, K. (2008). Inside the black box of regional development human capital, the creative class and tolerance. Journal of Economic Geography, 8, 615-649.

Gibbs, D. (2003). Ecological modernisation, regional economic development and regional development agencies. Geoforum 1, 9-19. 
INTERNATIONAL JOURNAL OF ACADEMIC RESEARCH IN BUSINESS AND SOCIAL SCIENCES

Vol. 10, No. 6, June, 2020, E-ISSN: 2222-6990 @ 2020 HRMARS

Gupta, J., Pouwb N. R. M., \& Ros-Tonen, M. A. F. (2015). Towards an Elaborated Theory of Inclusive Development. European Journal of Development Research, 27, 541-559. doi:10.1057/ejdr.2015.30.

Gupta, J., \& Vegelin, C. (2016). Sustainable development goals and inclusive development. International Environment Agreements, 16, 433-448.

Gent, S. V. (2017). Beyond buzzwords: What is "Inclusive Development? Synthesis report, INCLUDE Secretariat. https://www.semanticscholar.org/paper/Beyond-buzzwords-\%3A-What-is\%E2\%80\%9C-inclusive-development Gent/a85878b48436cfa49f556f6ad807f192909b85a3.

Guchait, S. (2017). Global Inclusive Growth for Sustainable Development: A New Approach. International Journal of Social Science and Humanities Research, 5(3), 270-283.

Hasan, M. M., \& Siddique, M. Z. R. (2016). Impacts of Tourism Development on Local Community: A Study on Shalban Vihara. Bangladesh Journal of Tourism, 1(1).

Hishammuddina, M. A. H., Linga, G. H. T., Chaua, L. W., Hoa, C. S., Hob, W. S., \& Idris, A. M. (2018). Circular Economy (CE): A Framework towards Sustainable Low Carbon Development in Pengerang, Johor, Malaysia. Chemical Engineering Transactions, 63, 481-486. doi:10.3303/CET186308.

Hwang, J., Park, J., \& Lee, S. (2018). The Impact of the Comprehensive Rural Village Development Program on Rural Sustainability in Korea. Sustainability, 10 (2436). doi:10.3390/su10072436.

Ida J., \& Terluin, I. J. (2003). Differences in economic development in rural regions of advanced countries: an overview and critical analysis of theories. Journal of Rural Studies, 19, 327-344.

Khoo, S. M. (1987). Documenting Papers on Bumiputra Participation in The Malaysian Economy. Library Review, 36(2), 110-121.

Lee, N. (2019). Inclusive Growth in cities: a sympathetic critique. Regional Studies, 53(3), 424-434. dol: $10.1080 / 00343404.2018 .1476753$.

Mackinnon, D., Cumbers, A., \& Chapman, K. (2002). Learning, innovation and regional development: a critical appraisal of recent debates. Progress in Human Geography, 26(3), 293-311.

Masser, I. (2006). Technology and Regional Policy: A Review of Japan Development 's Technopolis Program. Regional Studies, 24(1), 41-53.

Ngah, I. (1993). Business Activities in New Townships in Rural Areas of Peninsular Malaysia. Ph.D. Thesis University of Leeds, Woodhouse Leeds, United Kingdom.

Ngah, I., \& Saad, H. (2015). Business transition in Bandar Penawar, a new town in Kejora Region, Malaysia. 6th International Conference and Field Study in Indonesia RRPG2015 Managing Rural Transition at Urban Fringe Toward Sustainability, Bogor, Indonesia, 28-29 September 2015.

https://www.academia.edu/17951165/BUSINESS_TRANSITION_IN_BANDAR_PENAWAR_A_ NEW_TOWN_IN_KEJORA_REGION_MALAYSIA1.

Ngah, I. (2015). Inclusive Regional Development and the Pathways for Addressing Socio-Spatial Inequality. International Conference on Development and Socio-Spatial Inequalities, Bayview Beach Resort, Penang, Malaysia, 19 - 20 August 2015.

https://www.researchgate.net/publication/283077227_INCLUSIVE_REGIONAL_DEVELOPME NT_AND_THE_PATHWAYS_FOR_ADDRESSING_SOCIO-

SPATIAL_INEQUALITY/citation/download.

Pouw, N., \& Gupta, J. (2017). Inclusive Development: A Multi-Disciplinary Issue. Current Opinion in Environmental Sustainability, 24, 104-108. doi.org/10.1016/j.cosust.2016.11.013. 
INTERNATIONAL JOURNAL OF ACADEMIC RESEARCH IN BUSINESS AND SOCIAL SCIENCES Vol. 10, No. 6, June, 2020, E-ISSN: 2222-6990 @ 2020 HRMARS

Raunayar, G., \& Kanbur, R. (2009). Conceptualizing Inclusive Development: With Applications to Rural Infrastructure and Development Assistance. Asian Development Bank, Occasional Paper No. 7. https://www.adb.org/sites/default/files/evaluation document/35886/files/op7-conceptualizing-inclusive-development.pdf.

Raunayar, G., \& Kanbur, R. (2009). Inclusive Growth and Inclusive Development: A Review and Synthesis of Asian Development Bank Literature. Asian Development Bank, Occasional Paper No. 8. https://www.adb.org/sites/default/files/evaluation document/35885/files/op8inclusive-growth-development.pdf.

Royon, E. P., \& Geiser, P. (2009). Inclusive Local Development, how to implement a disability approach at the local level? Handicap International, Policy paper. Retrieved from: https://www.researchgate.net/publication/261697407_Inclusive_Local_Development_how _to_implement_a_disability_approach_at_the_local_level/citation/download.

Rahman, S. (2018). Trends in Southeast Asia, Developing Eastern Johor: The Pengerang Integrated Petroleum Complex. ISEAS Publishing: 30 Heng Mui Keng Terrace Singapore. https://www.iseas.edu.sg/images/pdf/TRS16_18.pdf/www.iseas.edu.sg/images/pdf/TRS16_ 18.pdf.

Rohani, A., Sahid, M. S., Hasbullah, M. H., Suliman, S., Ariff, A. H., Samsudin, S., \& Suratman, R. (2019). Land Acquisition in Malaysia: Policy Context and Praxis for Oil and Gas hub project in Eastern Johor. World Bank Conference on Land and Poverty, the world bank - Washington DC, March 25-29, 2019.

Shen, L. Y., Hao, J. L., Tam, V. W. Y., \& Yao, H. A. (2007). checklist for assessing sustainability performance of construction projects. Journal of Civil Engineering and Management, 13, 273-281.

Sev, A. (2009). How can the construction industry contribute to sustainable development? A conceptual framework. Sustainable Development, 17, 161-173. 10.1002/sd.373.

Tsymbaliuk, I. (2019). Principles of Inclusive Regional Development in the Conditions of Financial Decentralization. Innovative Economy, 5(6), 125-132.

Taiwo, A. M., Ayodeji, M. A., \& Yusuf, A. B. (2012) Impact of Small and Medium Enterprises on Economic Growth and Development. American Journal of Business and Management, 1(1), 18-22.

Warr, P., Menon, J., \& Yusuf, A. A. (2010). Regional Economic Impacts of Large Projects: A General Equilibrium Application to Cross-Border Infrastructure. Asian Development Review, 27(1), 104-134.

Widianingsih, I., \& Paskarina, C. (2019). Defining Inclusiveness in Development: Perspective from Local Government's Apparatus. Jurnal Bina Praja, 11(2), 137-147.

Xiahou, X., Tang, Y. J., Yuan, J., Chang, T., Liu, P., \& Li, Q. (2018). Evaluating Social Performance of Construction Projects: An Empirical Study. Sustainability, 10, 2329. Doi:10.3390/su10072329.

Zahid, M. M., \& Nasir, Z. M. (2016). Study on Optimum Peripheral Business Model in Pengerang, Johor. International Journal of Management Science and Business Administration, 2(2),2940. 10.18775/ijmsba.1849-5664-5419.2014.22.1003. 